\title{
Kemampuan Literasi Matematika Peserta Didik Kelas IX berdasarkan Gaya Belajar menurut David Kolb
}

\author{
Syifa'ul Furqon ${ }^{1}$, Emy Siswanah ${ }^{2}$, Dyan Falasifa Tsani ${ }^{3}$ \\ ${ }^{123}$ Program Studi Pendidikan Matematika, Universitas Islam Negeri Walisongo Semarang \\ E-mail: syipaulfurqon23@gmail.com ${ }^{1}$
}

\begin{abstract}
Abstrak
Tujuan penelitian ini ialah mengetahui karakteristik kemampuan literasi matematika peserta didik kelas IX berdasarkan gaya belajar menurut David Kolb. Penelitian ini menggunakan pendekatan deksriptif analitis dengan subjek penelitian peserta didik kelas IX A SMP 4 Pemalang tahun pelajaran 2019/2020. Hasil riset menyatakan bahwa Subjek Diverger Tinggi, Sedang dan Bawah mampu menyelesaikan permasalahan literasi matematika level 2, 3 dan 5. Subjek Assimilator Atas mampu menyelesaikan permasalahan literasi matematika level 2, 3, 4, 5 dan 6. Assimilator Tengah tuntas pada level 2, 3, 5 dan 6. Subjek Assimilator Bawah hanya tuntas pada level 2, 3, dan 5. Subjek Converger Atas mampu menyelesaikan literasi matematika level 2, 3, 4, 5, dan 6. Subjek Converger Tengah tuntas pada level 2, 5 dan 6 kemudian kurang mampu pada level 3. Converger Bawah tuntas pada level 2 dan 3 kemudiann kurang mampu pada level 4. Subjek Accomodator Atas mampu menyelesaikan permasalahan literasi matematika level 3, 4, 5, dan 6 kemudian kurang mampu pada level 2. Accomodator Tengah tuntas pada level 2 dan 3. sedangkan Accomodator Bawah hanya mampu menyelesaikan soal level 2 dan kurang mampu menyelesaikan permasalahan literasi matematika level 3.
\end{abstract}

Kata Kunci: David Kolb, gaya belajar, kelas IX, literasi matematika.

\section{Mathematical Literacy Skill of IX Grade Student in term of David Kolb Learning Style}

\begin{abstract}
The purpose of this study was to determine the characteristics of mathematical literacy skills of class IX students based on learning styles according to David Kolb. This study uses an analytical descriptive approach with research subjects of class IX A students of SMP 4 Pemalang in the academic year 2019/2020. The results of the study stated that High, Medium and Lower Diverger Subjects were able to solve math literacy problems level 2, 3 and 5. The Upper Assimilator Subject was able to solve math literacy problems level 2, 3, 4, 5 and 6. The Middle Assimilator was complete at levels 2, 3, 5 and 6. The Lower Assimilator Subject is only completed at levels 2, 3, and 5. The Upper Converger Subject is able to complete level 2, 3, 4, 5, and 6 mathematics literacy. less able at level 3. Lower Converger is complete at level 2 and 3 then less able at level 4. Upper Accomodator subject is able to solve mathematical literacy problems level 3, 4, 5, and 6 then less able at level 2. Middle Accomodator is complete at level 2 and 3. whereas Lower Accommodation is only able to solve level 2 problems and less able to solve level 3 mathematical literacy problems.
\end{abstract}

Keywords: class IX, David Kolb, learning style, mathematic literacy 


\section{PENDAHULUAN}

Kemendikbud mengungkapkan alasan adanya perubahan kurikulum menjadi kurikulum 2013 dikarenakan rendahnya hasil riset internasional terkait kualitas peserta didik (Juliantari, 2013). Lembaga tersebut yakni PISA, TIMMS dan PIRLS. Ketiga lembaga ini berfokus pada pengukuran prestasi dan kemampuan kognitif peserta didik. PISA khususnya, mengukur kemampuan keberaksaraan (literasi) peserta didik yang meliputi literasi membaca, sains dan matematika. Tercatat pada tahun 2015, Indonesia hanya mendapatkan rata-rata skor 386 pada tes kemampuan literasi matematika (OECD, 2016). Dengan skor tersebut, Indonesia masih menduduki 10 peringkat terbawah. Oleh karena rendahnya hasil riset oleh ketiga lembaga tersebut, Kemendikbud mengambil jalan mengubah kurikulum menjadi kurikulum 2013 dan juga mewajibkan dalam pembelajaran matematika terimplikasi kegiatan peningkatan Kemampuan Literasi Matematika (KLM).

Literasi matematika ini dinilai sejalan dengan tujuan pendidikan nasional dalam UndangUndang No. 20 tahun 2003. Lebih lanjut adanya literasi matematika ini bertujuan meningkatkan karakter bangsa sebagaimana tertuang secara implisit pada Permendikbud nomor 21 tahun 2015 tentang penumbuhan budi pekerti. Kemudian jika ditelisik lebih lanjut Literasi Matematika merupakan integrasi dari berbagai kompetensi yang tertuang pada Permendikbud Nomor 22 Tahun 2006.

Soleh (2017: 4) mendefinisikan literasi matematika sebagai kecakapan individu untuk merumuskan, mengaplikasikan dan menafsirkan matematika dalam berbagai konteks, termasuk kemampuan menalar secara matematis dan memanfaatkan konsep, prosedur, fakta, sebagai alat untuk mendeskripsikan, menjelaskan dan memprediksi suatu fenomena atau kejadian. Literasi matematika penting dimiliki generasi saat ini. Sari (2015) menuturkan bahwa literasi matematika mendorong sensivitas seorang individu dalam memahami penggunaan matematika pada kehidupan kesehariannya. Sensivitas ini akan membantu seseorang untuk berpikir numeris dan spasial dalam rangka menginterpretasikan dan menganalisis secara kritis situasi sehari-hari dengan lebih yakin.

Jika seorang peserta didik memiliki kemampuan literasi matematika, maka peserta didik tersebut mampu menyiapkan diri dalam pergaulan di masyarakat modern (OECD, 2016). Hal ini karena matematika tidak hanya memiliki peran sebagai disiplin ilmu pengetahuan namun juga berhubungan dengan pengaplikasiannya ke dalam masalah kehidupan sehari-hari (real world problem). Kemampuan literasi matematika mampu membantu peserta didik untuk memahami kaidahkaidah yang menjadikan matematika mampu diterapkan pada kenyatakan dan untuk membuat pertimbangan juga keputusan yang dibutuhkan dengan mengonstruksi, menggunakan, dan merefleksikan diri sebagai warga masyarakat.

Kemampuan literasi matematika didasari delapan kemampuan dasar yakni, berpikir dan bernalar, argumentasi, komunikasi, pemodelan, menyatakan dan memecahkan masalah, representasi matematis, menggunakan simbol dan menggunakan alat dan teknologi (Lange, 1991: 77). Terdapat tiga komponen dalam Literasi Matematika yakni konten, proses, dan konteks. Selain itu, PISA membagi kemampuan literasi peserta didik dalam 6 tingkatan.

Melihat pentingnya kemampuan literasi matematika, maka perlu adanya tindakan untuk meningkatkan kemampuan tersebut. Selain suasana pembelajaran guna mendukung meningkatnya kemampuan literasi matematika, ada banyak faktor yang memengaruhi kemampuan literasi matematika peserta didik (Stacey, 2011) misalnya kondisi sosial ekonomi, gender, perhatian orang tua dan lainnya. Selain itu, faktor lain yang perlu menjadi perhatian ialah perbedaan setiap peserta didik ialah gaya belajarnya. Gaya belajar ini perlu diperhatikan guna mengembangkan diri secara maksimal sesuai dengan kemampuan yang dimiliki peserta didik. Selain itu, dengan mengetahui gaya belajar peserta didik guru dapat memberikan strategi pembelajaran yang efektif.

Memahami gaya belajarnya merupakan salah satu kunci keberhasilan seseorang dalam belajar (Azrai \& Sulistianingrum, 2017: 10). Gaya belajar merupakan cara-cara yang lebih disukai seseorang dalam melakukan kegiatan berpikir, memproses, dan mengerti suatu informasi. Selain itu, menurut Ghufron \& Risnawita (Azrai \& Sulistianingrum, 2017: 13) gaya belajar merupakan cara yang dibangun oleh masing-masing individu untuk berkonsentrasi pada proses dan menguasai informasi yang baru melalui persepsi yang berbeda. Kolb (1984) mendefinisikan gaya belajar adalah pilihan 
seorang individu dalam mengasosiasikan pengalaman dan proses perubahannya. Gaya belajar merepresentasikan karakteristik seseorang terhadap pengalaman yang dialaminya.

Gaya belajar David Kolb merupakan salah satu model gaya belajar yang berdasarkan pada proses pengolahan informasi (Hamidah \& Rosyidi, 2016). Kolb (1984), dalam pemikirannya mendefinisikan belajar sebagai proses dimana pengetahuan diciptakan melalui transformasi pengalaman. Pengetahuan dianggap sebagai perpaduan antara memahami dan mentransformasikan pengalaman. Van Dyne \& Ang (2009) menjelaskan bahwa terdapat empat tahapan dalam gaya belajar David Kolb yang terdiri dari concrete experience (pengalaman konkrit), reflective observation (obsetvasi reflektif), abstract consptualisation (konseptualisasi abstrak), dan active experimental (percobaan aktif).

Fatkhiyyah, Winarso \& Manfaat $(2019$, 96) menjabarkan pada tahap concrete experience, pembelajaran diberikan rangsangan/stimulus agar dapat mendorong untuk melakukan suatu tindakan tertentu. Tindakan tersebut berasal dari pengalaman sebelumnya dan dapat dilakukan secara kelompok atau pribadi. Pada tahap reflective observation, pembelajaran dilakukan dengan mengamati dan merefleksikan pengalaman, sehingga akan menghasilkan sebuah kesimpulan yang dapat dijadikan sebuah pembelajaran. Pada abstrack conceptualisation, pembelajaran berupa pembentukan konsep mulai dari mengkonseptualisasi suatu teori dari pengalaman dan mengintegrasikan dengan pengalaman sebelumnya. Sedangkan pada tahap active experimental, pembelajaran diarahkan untuk melakukan percobaan terhadap hasil kesimpulan yang diperoleh sebelumnya yang dijadikan sebagai sebagai pembelajaran.

Seseorang belajar dari pengalamannya yang lalu (pengalaman konkrit), kemudian pengalaman tersebut diamati dengan baik (observasi reflektif), dipikirkan untuk menghasilkan sebuah kesimpulan atau dugaan (konseptualisasi abstrak) dan kemudian kesimpulan tersebut diuji cobakan dengan mencoba untuk melakukan suatu tindakan (eksperimentasi aktif) (Kolb, 2014). Hal tersebut menjadi pengalaman baru yang kemudian diamati kembali dan seterusnya mengikuti siklus belajar menurut David Kolb.

Suyono dan Hariyanto (2011) menjelaskan agar belajar belajar menjadi efektif setiap pembelajar harus berusaha memadukan keempat kecenderungan tersebut. Meskipun setiap individu mencoba untuk memadukan keempat pendekatan tersebut dalam belajar, namun mereka cenderung lebih kuat pada dua kecenderungan yakni pada pendekatan perolehan pengalaman, dan pendekatan transformasi pengalaman. Keempat kecenderungan belajar tersebut bila dikombinasikan akan membentuk empat tipe gaya belajar yaitu gaya belajar Diverger (CE \& RO), Assimilator (AC \& RO), Converger (AC \& AE), dan Accomodator (CE \& AE).

Setiap peserta didik mempunyai keunikannya sendiri, perlu diperhatikan bahwa gaya belajar peserta didik mempengaruhi bagaimana peserta didik memproses informasi yang didapatkannya. Metode dan pendekatan pembelajaran yang tepat dapat meningkatkan kemampuan dan pemahaman peserta didik. Berdasarkan pemaparan di atas maka penelitian ini bertujuan untuk mendeskripsikan karakteristik peserta didik dalam menyelesaikan soal tes kemampuan literasi matematika ditinjau dari gaya belajar menurut David Kolb.

\section{METODE}

Jenis penelitian yang dilakukan ialah deskriptif analitik (Sugiyono, 2018). Penelitian dilakukan di SMP N 4 Pemalang yang beralamat di Jl. Sumbing No. 2, Mulyoharjo, Kec. Pemalang, Kabupaten Pemalang, Jawa Tengah. Penelitian ini dilakukan pada tahun pelajaran 2019/2020 pada kelas IX tepatnya pada awal semester gasal bulan pertengahan juli hingga awal agustus tahun 2019. Pemilihan waktu penelitian ini guna mendapatkan data peserta didik yang notabene telah mendapatkan semua materi kelas VIII dan belum mendapatkan materi matematika kelas IX secara penuh dikarenakan peneliti membatasi materi pada kelas VIII.

Teknik pengumpulan data berupa tes, angket gaya belajar, wawancara dan dokumentasi. Tes digunakan untuk mengetahui tingkat kemampuan literasi matematika. Indikator yang digunakan ialah 6 level kemampuan literasi matematika sebagaimana telah di jabarkan oleh PISA (OECD, 2016). Soal yang diujikan kepada peserta didik ialah 6 buah soal literasi matematika dengan rentang level 2-6 yang telah melalui uji validitas, reliabilitas, tingkat kesukaran dan daya beda seperti pada tabel 1. 
Tabel 1. Data dan Sumber Data

\begin{tabular}{cccc}
\hline Data & Teknik & Instrumen & Sumber Data \\
\hline Paya Belajar Siswa & Angket & $\begin{array}{c}\text { 26 Butir Pernyataan } \\
\text { Lembar Tes Tulis } \\
(6 \text { item soal })\end{array}$ & Peserta Didik \\
$\begin{array}{c}\text { Kemampuan Literasi } \\
\text { Matematika }\end{array}$ & Tes & Peserta Didik \\
\hline
\end{tabular}

Angket digunakan untuk mengelompokkan peserta didik ke dalam tipe gaya belajar menurut David Kolb. Wawancara digunakan untuk mendapatkan informasi terkait karakteristik peserta didik dalam mengerjakan soal tes kemampuan literasi matematika. Sedangkan dokumentasi digunakan untuk mendapatkan data-data pendukung terkait penelitian yang dilakukan.

Penelitian ini melibatkan peserta didik kelas IX A SMP Negeri 4 Pemalang sebanyak 32 peserta didik sebagai sumber data. Dalam penelitian ini mulanya terdapat 32 peserta didik yang berpartisipasi dalam pengisian angket pada tanggal 18 Juli 2019. Kemudian pada pelaksanaan peserta tes kemampuan literasi matematika tanggal 23 Juli 2019 terdapat 31 peserta didik yang berpartisipasi, satu peserta didik tidak dapat mengikuti dikarenakan tidak berangkat. Dari 31 peserta didik yang berpartisipasi dalam tes kemampuan literasi matematika akan direduksi menjadi 12 peserta didik sebagai subjek penelitian. Pertimbangan pengambilan subjek penelitian didasarkan hasil angket gaya belajar yang dikombinasikan dengan hasil tes kemampuan literasi matematika. Subjek penelitian ini nantinya akan dilakukan wawancara untuk mendapatkan informasi lebih mendalam mengenai karakteristik kemampuan literasi matematika dari masing-masing gaya belajar.

Wawancara dilakukan dengan 12 peserta didik dengan pembagian masing-masing tiga peserta didik yang mewakili setiap gaya belajar. Pembagian peserta didik tersebut dipilih berdasarkan tingkatan kemampuannya yakni tinggi, sedang, dan bawah yang didapatkan dari hasil tes kemampuan literasi matematika. Pemilihan subjek berdasarkan tingkatan tinggi, sedang dan bawah ini diharapkan hasilnya dapat mengukur siswa secara keseluruhan. Penentuan kategori ini menggunakan perhitungan menurut Arikunto $(2016,299)$, yakni:

a. Kelompok Atas, semua responden yang mempunyai skor sebanyak skor mean plus $1(+1)$ standar deviasi $(\mathrm{x} \geq$ Mean $+\mathrm{SD})$.

b. Kelompok Tengah, semua responden yang mempunyai skor antara skor mean minus 1 standar deviasi dan skor rata-rata plus 1 standar deviasi (antara $($ Mean - SD) $\leq \mathrm{x}<($ Mean $+\mathrm{SD}))$

c. Kelompok Bawah, Kelompok responden yang mempunyai skor lebih rendah dari skor mean minus 1 standar deviasi ( $x$ Mean - 1 SD)

Teknik analisis data pada penelitian ini mengacu teknik analisis data menurut Miles \& Huberman: Reduksi Data (Data Reduction), Penyajian Data (Data Display), dan Kesimpulan (Conslusion Drawing/Verification) (Sugiyono, 2018, 246). Uji keabsahan data dalam penelitian ini meliputi (Sugiyono, 2018, 267-76): uji kredibilitas (Credibility) dan uji keteralihan (transferability).

Uji kredibilitas (Sugiyono 2018, 267-73) dalam penelitian ini menggunakan teknik triangulasi berupa triangulasi sumber dan triangulasi teknik. Sedangkan uji keteralihan (Sugiyono, 2018, 276) dalam penelitian ini dilakukan dengan cara melakukan penulisan secara rinci terhadap data-data temuan yang diperoleh. Kemampuan literasi matematika dalam penelitian ini dinilai berdasarkan level kemampuan literasi matematika oleh PISA yang mana telah dijabarkan oleh Johar $(2011,36)$.

Kemudian dalam penelitian yang dilakukan, terdapat pengkategorian terhadap hasil dari triangulasi data yang dilakukan yakni: (1) Mampu, jika dalam hasil tes dan wawancara subjek dapat memberikan jawaban yang tepat, (2) Kurang mampu, jika subjek hanya mampu memberikan jawaban yang tepat pada wawancara namun tidak bisa menjawab soal tes dengan baik, misalnya dikarenakan waktu habis. dan (3) Tidak mampu, jika subjek tidak dapat memberikan jawaban yang tepat pada wawancara dan tes, atau subjek mampu mengerjakan hasil tes namun ternyata menyontek.

\section{HASIL DAN PEMBAHASAN}

\section{Deskripsi Gaya Belajar}

Pengisian angket gaya belajar dilaksanakan pada hari kamis, 18 Juli 2019. Berdasarkan data yang didapatkan, peneliti membagi peserta didik sesuai dengan gaya belajarnya. Hasil penelitian terhadap gaya belajar peserta didik kelas IX A ditunjukkan pada tabel berikut. 
Tabel 2. Distribusi Gaya Belajar Peserta Didik kelas IX A SMP N 4 Pemalang

\begin{tabular}{ccc}
\hline $\begin{array}{c}\text { Jenis Gaya } \\
\text { Belajar }\end{array}$ & $\begin{array}{c}\text { Jumlah peserta } \\
\text { didik }\end{array}$ & Persentase (\%) \\
\hline Diverger & 3 & $9.38 \%$ \\
Assimilator & 11 & $34.38 \%$ \\
Converger & 8 & $25.00 \%$ \\
Accomodator & 10 & $31.25 \%$ \\
\hline Jumlah & 32 & $100 \%$ \\
\hline
\end{tabular}

Berdasarkan tabel di atas, mayoritas peserta didik kelas IX A SMP N 4 Pemalang memiliki gaya belajar Assimilator. Terdapat sebanyak 11 peserta didik yang memiliki karakteristik gaya belajar Assimilator. Kemudian, ada 10 peserta didik digolongkan dalam kategori gaya belajar Accomodator. Terdapat 8 peserta didik yang dikategorikan dalam gaya belajar Converger. Kemudian, ada 3 peserta didik yang termasuk dalam ketegori gaya belajar Diverger.

\section{Data Kemampuan Literasi Matematika}

Data Kemampuan Literasi Matematika (KLM) diperoleh dari pengujian butir tes yang berjumlah 6 soal yang telah dilaksanakan analisis uji instrumen tes. Soal diberikan kepada peserta didik kelas IX A SMP N 4 Pemalang pada tanggal 23 Juli 2019. Terdapat 31 orang yang berpartisipasi dalam tes kemampuan literasi tersebut.

Hasil tes KLM peserta didik kemudian dikelompokkan sesuai kategori gaya belajar peserta didik. Dalam penelitian ini terdapat enam soal yang mewakili level 2-6 yang telah melalui uji validitas, reliabilitas, tingkat kesukaran dan daya beda. Soal-soal tersebut dinyatatakan dalam tabel 3 Berikut soal-soal yang digunakan dalam tes kemampuan literasi matematika.

Tabel 3. Instrumen Soal Literasi Matematika

1. Ada 10 kuis yang diadakan semester ini. Nilai Anjani untuk 9 kuis matematika yang telah diadakan dinyatakan dalam diagram berikut:

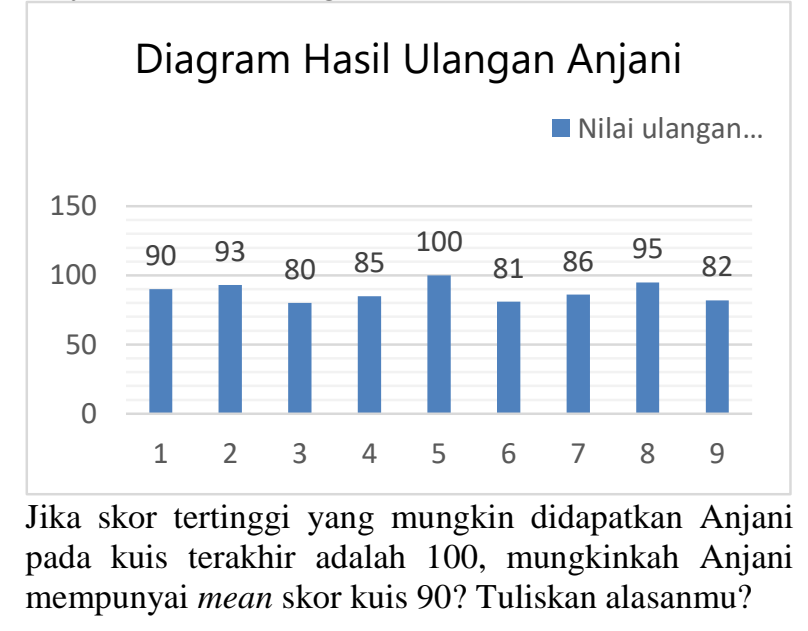

2. Perhatikan gambar di bawah ini
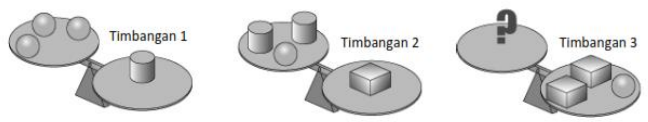

Timbangan 1 dan 2 berisi bola, silinder, dan kubus dengan keseimbangan sempurna. Berapa banyak silinder yang dibutuhkan agar timbangan
4. Bima merupakan mahasiswa yang sedang berkuliah di Amsterdam. Bima mempunyai banyak sahabat yang kuliah di berbagai negara. Sahabat tersebut yakni Yusuf (Cairo), Joko (Jakarta), Fatimah (Jeddah), Ayu (London), Musa (Madrid), Rama (Mexico City), Yumna (Sydney), Fiki (Tokyo) dan Dewi (Washington).

\begin{tabular}{|c|l|c|}
\hline No & \multicolumn{1}{|c|}{ Kota/Negara } & +/- GMT \\
\hline 1 & Amsterdam (Belanda) & +1 \\
\hline 2 & Cairo (Mesir) & +2 \\
\hline 3 & Jakarta (Indonesia) & +7 \\
\hline 4 & Jeddah (Arab) & +3 \\
\hline 5 & London (Inggris) & +0 \\
\hline 6 & Madrid (Spanyol) & +1 \\
\hline 7 & Mexico City (Mexico) & -6 \\
\hline 8 & Sydney (Australia) & +10 \\
\hline 9 & Tokyo (Jepang) & +9 \\
\hline 10 & Washington (Amerika) & -5 \\
\hline
\end{tabular}

Bima ingin melakukan video call bersama sahabatsahabatnya pada pukul 19.00 waktu setempat. Jika sahabatnya tidur pada pukul 21.00 - 04.30 waktu setempat. Tentukan siapa sajakah sahabatnya yang dapat dihubungi?

5. Sebuah konser musik akbar tengah berlangsung di pantai Widuri Pemalang. Konser tersebut berlangsung meriah. Terlihat penonton berdesakan menonton band yang sedang tampil. Jika penyelenggara hanya menyediakan tempat untuk menonton berbentuk persegi panjang dengan panjang 100 x 60 Meter. Berapakah kira-kira perkiraan jumlah penonton? 
3 seimbang? Sertakan perhitunganmu?
A. 6.000 orang
B. 12.000 orang
C. 24.000 orang
D. 32.000 orang

3. Di sebelah kanan, terdapat gambar dari beberapa buah dadu. Nomer-nomer pada dadu mempunyai keunikan yakni:

Jumlah dari titik (lingkaran) pada dua sisi yang bersebrangan jumlahnya selalu tujuh.

Kamu dapat membuat sebuah dadu dengan bantuan kertas. Terdapat banyak cara untuk membuat dadu. Dari bentuk-bentuk di bawah ini, manakah yang dapat membentuk sebuah dadu? Tuliskan alasanmu!

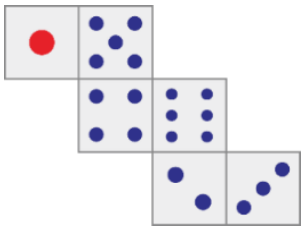

(I)

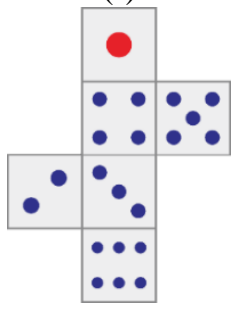

(III)

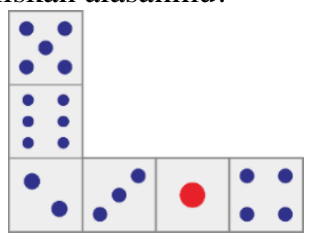

(II)

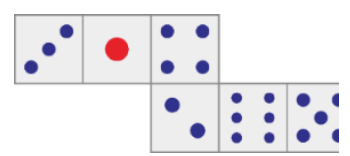

(IV)
6. Seorang tukang kayu diminta membuat pagar mengitari lahan peternakan di daerah Desa Danasari. Apabila Ia diminta membuat pagar dengan keliling 32 meter. Manakah bentuk lahan peternakan di bawah ini yang tidak mungkin dibuatkan pagar? (Soal diadaptasi dari tes PISA)

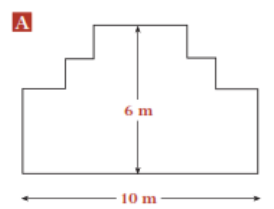

C

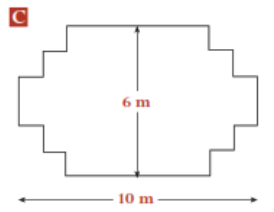

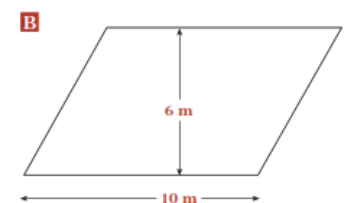

D

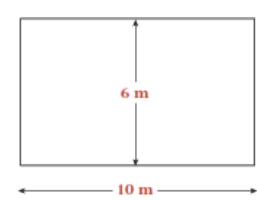

\begin{tabular}{|c|c|c|}
\hline Bentuk & Ya/Tidak & Alasan \\
\hline $\mathrm{A}$ & $\mathrm{Y} / \mathrm{T}$ & \\
\hline $\mathrm{B}$ & $\mathrm{Y} / \mathrm{T}$ & \\
\hline $\mathrm{C}$ & $\mathrm{Y} / \mathrm{T}$ & \\
\hline $\mathrm{D}$ & $\mathrm{Y} / \mathrm{T}$ & \\
\hline
\end{tabular}

\begin{tabular}{|c|c|c|}
\hline Bentuk & Ya/Tidak & Alasan \\
\hline I & Y / T & \\
\hline II & Y / T & \\
\hline III & Y / T & \\
\hline IV & Y / T & \\
\hline
\end{tabular}

Soal Level 2 (Soal Nomor 1)

Butir soal nomor 1 pada penelitian ini merepresentasikan KLM level 2. Syawahid \& Putrawangsa $(2017,228)$ mengungkapkan pada level ini peserta didik mampu menerjemahkan dan mengetahui kondisi dan konteks yang membutuhkan pengambilan kesimpulan langsung. Mereka mampu mengerjakan algoritma dasar, menggunakan rumus, melaksanakan prosedur atau kesepakatan kemudian memberikan alasan secara tepat dari hasil penyelesaiannya.

Soal nomor 1 berhubungan dengan konten ketidakpastian dan data (Uncertainty and Data) atau dalam kurikulum matematika berhubungan dengan teori peluang atau statistik. Peserta didik diminta menerka nilai akhir jika diketahui rata-rata dan nilai kuis sebelumnya.

\section{Soal Level 3 (Soal Nomor 2 dan 3)}

KLM Level 3 diinterpretasikan dengan soal nomor 2 dan 3. Syawahid \& Putrawangsa (2017, 228) mengungkapkan Pada level ini peserta didik dapat menjalankan suatu prosedur dengan jelas, termasuk prosedur yang membutuhkan keputusan secara berututan. Subjek mampu memecahkan problem, dan menerapkan strategi yang sederhana. 
Butir soal nomor 2 berhubungan dengan konten perubahan dan hubungan (Change and Relationship) atau dalam pembelajaran matematika berhubungan dengan fungsi dan aljabar. Pada butir soal ini peserta didik diminta menghitung banyaknya silinder yang dibutuhkan sehingga timbangan seimbang. Butir soal nomor 3 berhubungan dengan konten bangun dan ruang (Shape and Space) atau dalam pembelajaran matematika yakni geometri. Pada butir soal ini peserta didik diminta menerka gambar yang merupakan jaring-jaring kubus/dadu beserta memberikan alasannya.

\section{Soal Level 4 (Soal Nomor 4)}

KLM level 4 diinterpretasikan dengan butir soal nomor 4. Syawahid \& Putrawangsa $(2017,228)$ mengungkapkan pada level ini peserta didik dapat bekerja secara efektif dengan model dalam kondisi yang konkret tetapi kompleks. Peserta didik mampu menetapkan dan menggabungkan representasi yang berbeda termasuk simbol untuk menghubungkan dengan situasi nyata.

Butir soal nomor 4 berhubungan dengan konten perubahan dan hubungan (Change and Relationship). Pada butir soal ini, peserta didik diminta menyelesaikan permasalahan yang berhubungan dengan konsep zona waktu.

\section{Soal Level 5 (Soal Nomor 5)}

Butir soal nomor 5 KLM level 5. Syawahid \& Putrawangsa $(2017,227)$ mengungkapkan Pada level 5 ini, peserta didik mampu memilih, membandingkan, dan mengevaluasi dengan tepat strategi pemecahan masalah terkait dengan permasalahan kompleks yang berhubungan dengan model.

Butir soal ini berhubungan dengan konten kuantitas (Quantity) atau dalam pembelajaran matematika berkaitan dengan bilangan dan pola bilangan. Pada butir soal nomor 5, Peserta didik diminta menerka jumlah penonton konser yang mungkin memempati suatu tempat yang terbatas.

\section{Soal Level 6 (Soal Nomor 6)}

KLM Level 6 diinterpretasikan dengan butir soal nomor 6. Syawahid \& Putrawangsa (2017, 227) mengungkapkan pada level ini, peserta didik mampu melakukan pengonsepan, generalisasi dan menggunakan informasi berdasarkan penelaahan dalam situasi yang kompleks. Peserta didik mampu menerapkan pengetahuan, penguasaan dan hubungan simbol dan operasi matematika, untuk mengembangkan strategi dan penemuan baru. Peserta didik pada tingkatan ini memiliki kemampuan berpikir dan bernalar matematika yang tinggi.

Soal nomor 6 berhubungan dengan konten bangun dan ruang (Shape and Space). Pada soal ini peserta didik diminta menentukan bentuk yang memenuhi persyaratan ukuran keliling yang diminta disertai alasannya.

Tabel 4. Rekapitulasi Nilai KLM Kelas IX A berdasarkan Gaya Belajar

\begin{tabular}{|c|c|c|c|c|c|c|c|c|c|}
\hline \multirow{2}{*}{ No } & \multirow{2}{*}{ Gaya Belajar } & \multicolumn{6}{|c|}{ Skor Per Soal } & \multirow{2}{*}{ Jumlah } & \multirow{2}{*}{ Nilai } \\
\hline & & 1 & 2 & 3 & 4 & 5 & 6 & & \\
\hline 1 & Diverger & 25,0 & 35,0 & 40,0 & 32,0 & 47,3 & 31,0 & 210,3 & 82,48 \\
\hline 2 & Assimilator & 25,0 & 28,2 & 39,5 & 39,8 & 43,9 & 50,5 & 227,0 & 89,02 \\
\hline 3 & Converger & 23,4 & 25,0 & 34,8 & 38,8 & 41,6 & 55,3 & 218,8 & 85,81 \\
\hline \multirow[t]{2}{*}{4} & Accomodator & 22,3 & 30,6 & 36,1 & 33,8 & 34,8 & 42,4 & 200,1 & 78,45 \\
\hline & & 25 & 35 & 40 & 45 & 50 & 60 & 255 & \\
\hline
\end{tabular}

Tabel di atas merupakan rekapitulasi nilai KLM kelas IX A berdasarkan gaya belajarnya. Dalam diagram tersebut nampak gaya belajar Assimilator mendapatkan rata-rata skor tertinggi yakni 89,02. Gaya belajar Converger mendapatkan rata-rata skor 85,81. Kemudian gaya belajar Diverger mendapatkan skor 82.48. Dan yang terakhir gaya belajar Accomodator mendapatkan skor rata-rata 78,75 .

Berdasarkan pemaparan data di atas untuk mengetahui karakteristik dari setiap gaya belajar dalam mengerjakan soal KLM. Data dianalisis dan dipilih masing-masing kategori sebanyak 3 peserta 
didik per-gaya belajar sebagai subjek wawancara. Tiga Subjek penelitian tersebut dipilih berdasarkan tingkatan skor yakni tinggi, sedang dan bawah. Berikut daftar subjek yang terpilih:

Tabel 5. Skor Persubjek Penelitian

\begin{tabular}{cccc}
\hline No & Kode & Kategori Gaya Belajar & Skor \\
\hline 1 & S-25 & Diverger Atas & 85.1 \\
2 & S-11 & Diverger Tengah & 82.0 \\
3 & S-32 & Diverger Bawah & 80.4 \\
4 & S-15 & Assimilator Atas & 99.4 \\
5 & S-21 & Assimilator Tengah & 90.6 \\
6 & S-14 & Assimilator Bawah & 76.9 \\
7 & S-26 & Converger Atas & 99.4 \\
8 & S-08 & Converger Tengah & 84.1 \\
9 & S-17 & Converger Bawah & 72.2 \\
10 & S-29 & Accomodator Atas & 95.3 \\
11 & S-10 & Accomodator Tengah & 75.7 \\
12 & S-02 & Accomodator Bawah & 61.0 \\
\hline
\end{tabular}

\section{Pembahasan Hasil Penelitian}

Kemampuan literasi matematika peserta didik gaya belajar Diverger

Subjek Diverger Atas mampu menyelesaikan permasalahan kemampuan literasi matematika level, 2, 3, dan 5. Dalam pekerjaannya, Subjek Diverger Atas mampu menemukan sudut pandang berbeda dalam menyelesaikan suatu permasalahan. Misalnya pada soal nomor 1, subjek tidak menggunakan konsep mean namun menggunakan konsep skor maksimal sebagai strategi pemecahan. Subjek kesulitan dalam mengerjakan soal yang membutuhkan pemikiran tingkat tinggi dan kompleks. Pada soal nomor 4 subjek mengetahui konsep zona waktu namun subjek kurang memahami maksud dari soal sehingga salah dalam menyimpulkan. Subjek tidak menemukan solusi pemecahan pada soal nomor 6. Subjek hanya mampu mengerjakan permasalahan yang umum ditemuinya.

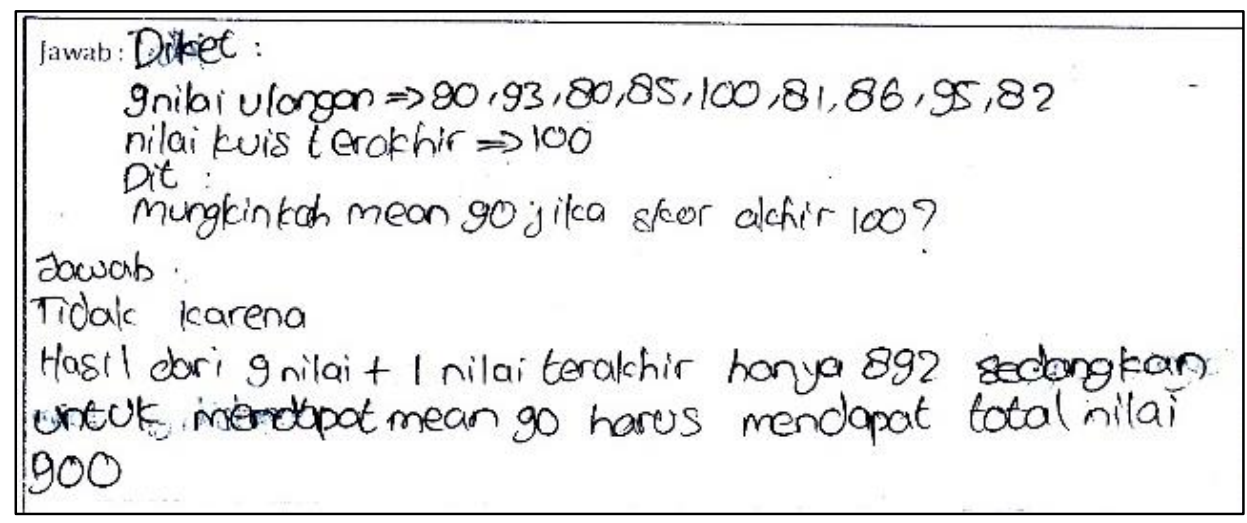

Gambar 1. Jawaban Subjek Diverger Atas pada Soal nomor 1

Subjek Diverger Tengah mampu menyelesaikan permasalahan kemampuan literasi matematika level, 2, 3, dan 5. Sama halnya dengan subjek Diverger Atas, Subjek Diverger tengah kesulitan menyelesaikan permasalahan matematika yang membutuhkan pemikiran tingkat tinggi dan kompleks. Subjek Diverger Tengah juga memiliki masalah serupa dengan subjek Diverger Atas yang belum memahami soal nomor 4 dengan tuntas dan kebingungan menemukan pemecahan soal nomor 6 . 


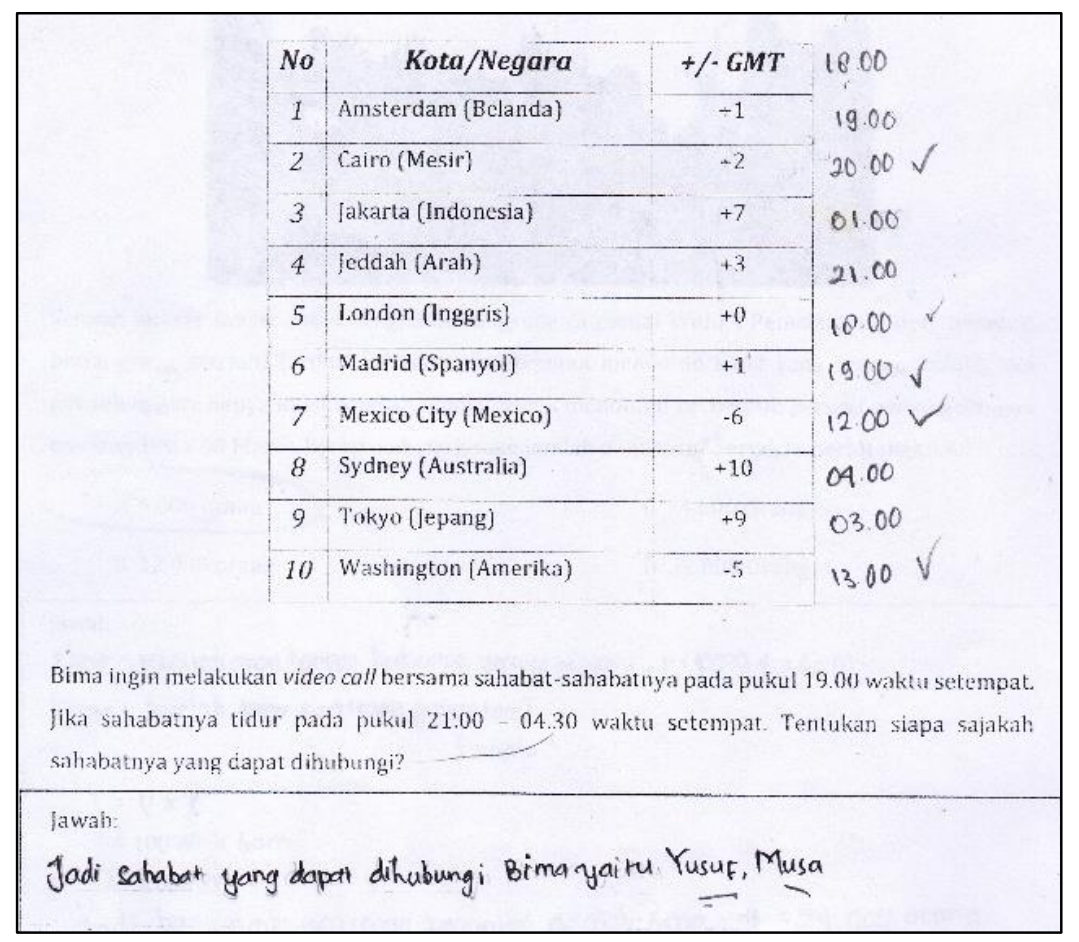

Gambar 2. Jawaban Subjek Diverger Tengah pada Soal nomor 4

Subjek Diverger Bawah mampu menyelesaikan permasalahan kemampuan literasi matematika level, 2, 3, dan 5. Subjek Diverger Bawah belum mampu memahami konsep zona waktu sehingga tidak mampu menemukan strategi pemecahan yang tepat untuk permasalahan nomor 4. Secara khusus, pada soal nomor 5, subjek Diverger memiliki kelebihan mampu menemukan sudut pandangan lain dalam menyelesaikan permasalahan.

Secara umum, dalam pekerjaannya Subjek Diverger menuliskan keterangan diketahui dan ditanyakan secara lengkap. Namun sering kali subjek Diverger belum sistematis dalam menuliskan jawabannya, subjek tidak menyertakan rumus dalam penulisan jawaban. Meskipun demikian subjek Diverger memiliki kelebihan dapat melihat situasi dari banyak sudut pandang (Kolb \& kolb, 2005) Dengan kemampuan itu Subjek dapat menemukan solusi pemecahan sederhana maupun memberikan suatu pemecahan yang berbeda dari lainnya.

Peserta didik dengan gaya belajar Diverger secara keseluruhan belum mampu menyelesaikan permasalahan yang merepresentasikan kemampuan literasi level 6. Peserta didik belum memiliki kemampuan berfikir dan berlogika matematika tingkat tinggi. Hal ini dikarenakan gaya belajar Diverger dibangun dari proses belajarnya yang cenderung berdasarkan perasaan/pengalaman konkret (Concrete Experience) dan pengamatan/observasi (Reflective Observation) (Kolb 1984) sehingga kurang ahli menyelesaikan permasalahan yang abstrak atau tidak pernah dialaminya. Meskipun demikian, Subjek Diverger memiliki kelebihan mampu melihat situasi dari banyak perspektif kemudian menghubungkannya dengan pengetahuan yang dimiliki untuk mencoba permasalahan pada nomor 6 meskipun tidak tepat. Ini sesuai dengan tipikal Diverger menurut Ghufron dan Riswawita (2014) yang mampu melihat dari berbagai sudut pandang dan tidak takut untuk mencoba.

Subjek dengan gaya belajar Diverger juga mempunyai kesulitan untuk menyelesaikan permasalahan kemampuan literasi matematika level 4. Subjek belum mampu menyelesaikan permasalahan dalam situasi konkret yang kompleks. Ketiganya kurang memahami soal secara keseluruhan sehingga belum mampu menyelesaikan permasalahan nomor 4. Menurut Ghufron dan Risnawita (2014) Subjek Diverger memiliki kekurangan cepat mudah bosan menyelesaikan permasalahan persoalan yang membutuhkan waktu yang lama seperti nomor 4. Akibarnya subjek menjadi kurang teliti dalam mengerjakan soal. Data ketercapaian level KLM gaya belajar Divergen dapat dilihat pada Tabel 6 . 
Tabel 6. Ketercapaian Level KLM Gaya Belajar Diverger

\begin{tabular}{ccccc}
\hline Level & No & Diverger Atas & Diverger Tengah & Diverger Bawah \\
\hline 2 & 1 & Mampu & Mampu & Mampu \\
& 2 & Mampu & Mampu & Mampu \\
3 & 3 & Mampu & Mampu & Mampu \\
4 & 4 & Tidak Mampu & Tidak Mampu & Tidak Mampu \\
5 & 5 & Mampu & Mampu & Mampu \\
6 & 6 & Tidak Mampu & Tidak Mampu & Tidak Mampu \\
\hline
\end{tabular}

\section{Kemampuan literasi matematika peserta didik gaya belajar Assimilator}

Subjek dengan gaya belajar Assimilator Atas mampu menyelesaikan permasalahan kemampuan literasi matematika level 2, 3, 4, 5 dan 6. Subjek Assimilator Atas mampu menyelesaikan seluruh permasalahan yang diberikan dengan baik. Dengan logika dan pengamatannya, Subjek Assimilator Atas menggunakan benda disekitarnya (keramik) untuk menerka opsi jawaban yang tepat untuk nomor 5. Selain itu pada soal nomor 6 subjek melakukan penerkaan ukuran gambar pada soal.

Subjek Assimilator Tengah mampu menyelesaikan permasalahan kemampuan literasi matematika level 2, 3, 5 dan 6. Subjek Assimilator Tengah mampu menyelesaikan seluruh permasalahan yang diberikan dengan baik. Berdasarkan analisis pada lembar jawabannya, Subjek Assimilator Tengah mempunyai kemampuan analisis yang baik sehingga mampu menyelesaikan tes kemampuan literasi hingga level 6. Namun subjek Assimilator Tengah memiliki kekurangan yakni kemampuan komunikasi yang kurang baik. Dalam menjawab pertanyaan subjek sering bingung dan perlu diarahkan untuk menjelaskan jawabannya.

Sedangkan subjek Assimilator Bawah hanya mampu memecahkan permasalahan kemampuan literasi matematika level 2, 3 dan 5. Subjek Assimilator Bawah belum mampu menemukan solusi pemecahan untuk soal nomor 4. Subjek juga kesulitan dalam mengerjakan soal literasi matematika level 6.

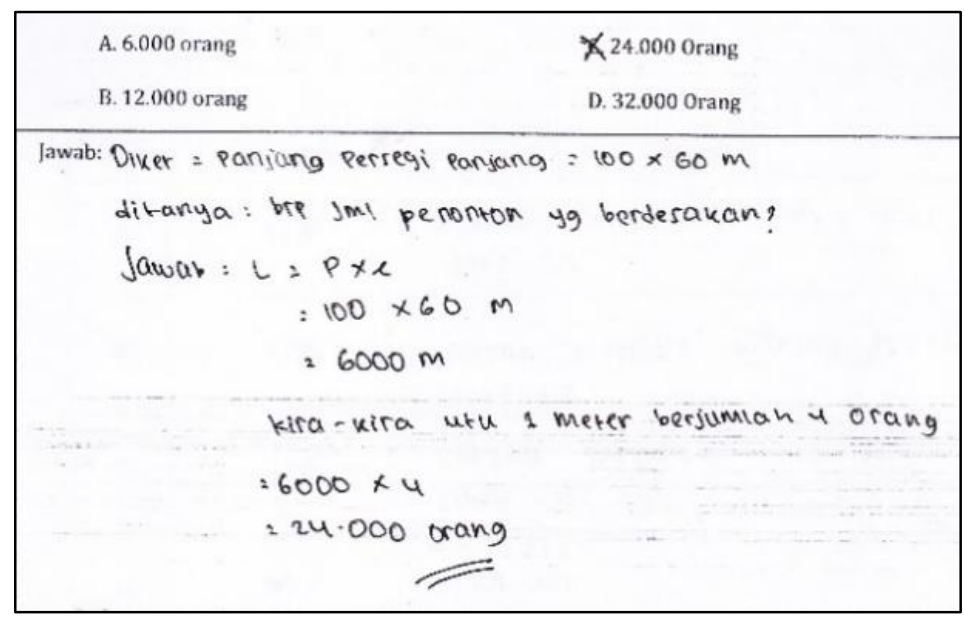

Gambar 3. Jawaban Subjek Assimilator Bawah pada Soal nomor 5

Gaya belajar Assimilator memiliki pengamatan yang baik, subjek mampu memahami berbagai sajian informasi dari berbagai sumber dan dipandang dari berbagai perspektif (Kolb \& Kolb, 2005). Menurut Ghufron dan Risnawita (2014) subjek Assimilator akan berusaha benar-benar memahami suatu permasalahan terlebih dahulu sebelum melakukan tindakan. Dengan kemampuannya ini, subjek Assimilator dapat menemukan solusi pemecahan untuk soal-soal yang membutuhkan kemampuan berpikir dan bernalar yang tinggi.

Subjek Assimilator memiliki pemikiran yang objektif, analitis, runtut dan sistematis yang didukung dengan sudut pandang dari berbagai perspektif (Kolb \& Kolb 2005; Ghufron and Risnawita 
2014). Sehingga subjek tidak kesulitan menyelesaikan soal yang berbentuk model prosedural ataupun soal-soal yang membutuhkan analisis mendalam layaknya soal nomor 2 dan 4.

Pendekatan yang digunakan oleh Assimilator ialah logika (Ghufron \& Risnawita, 2014). Meskipun jawaban yang ditulis oleh subjek Assimilator nampak singkat namun sebenarnya logis. Penulisan jawaban yang relatif singkat ini terkadang tidak dibarengi dengan penulisan jawaban yang sistematis dan lengkap. Subjek Assimilator seringkali tidak lengkap dalam penulisan keterangan diketahui maupun penulisan rumus. Subjek Assimilator diindikasi memiliki kemampuan spasial yang baik. Ini dilihat dari cara penyelesaian soal nomor 3 yang tidak menggunakan alat bantu untuk menyelesaikan memvisualisasikan bangun geometris. Data ketercapaian level KLM gaya belajar Assimilator dapat dilihat pada Tabel 7.

Tabel 7. Ketercapaian Level KLM Gaya Belajar Assimilator

\begin{tabular}{ccccc}
\hline Level & No & Assimilator Atas & Assimilator Tengah & Assimilator Bawah \\
\hline 2 & 1 & Mampu & Mampu & Mampu \\
& 2 & Mampu & Mampu & Mampu \\
3 & 3 & Mampu & Mampu & Mampu \\
4 & 4 & Mampu & Tidak Mampu & Tidak Mampu \\
5 & 5 & Mampu & Mampu & Mampu \\
6 & 6 & Mampu & Mampu & Tidak Mampu \\
\hline
\end{tabular}

\section{Kemampuan literasi matematika peserta didik gaya belajar Converger}

Subjek Converger Atas secara sempurna mampu menyelesaikan kemampuan literasi matematika level 2, 3, 4, 5, 6. Kolb \& Kolb (2005) mengungkapkan gaya belajar Converger memiliki pendekatan mengintegrasi apa yang diamatinya terlebih dahulu sebelum menyelesaikan permasalahan. Subjek Converger mampu memahami masalah yang diberikan kemudian menemukan solusi sederhana untuk menyelesaikan permasalahan yang diberikan. Pada soal nomor 6, subjek mengamati permasalahan yang diberikan kemudian bekerja dengan logikanya lalu menemukan generalisasi dari permasalahan yang diberikan.

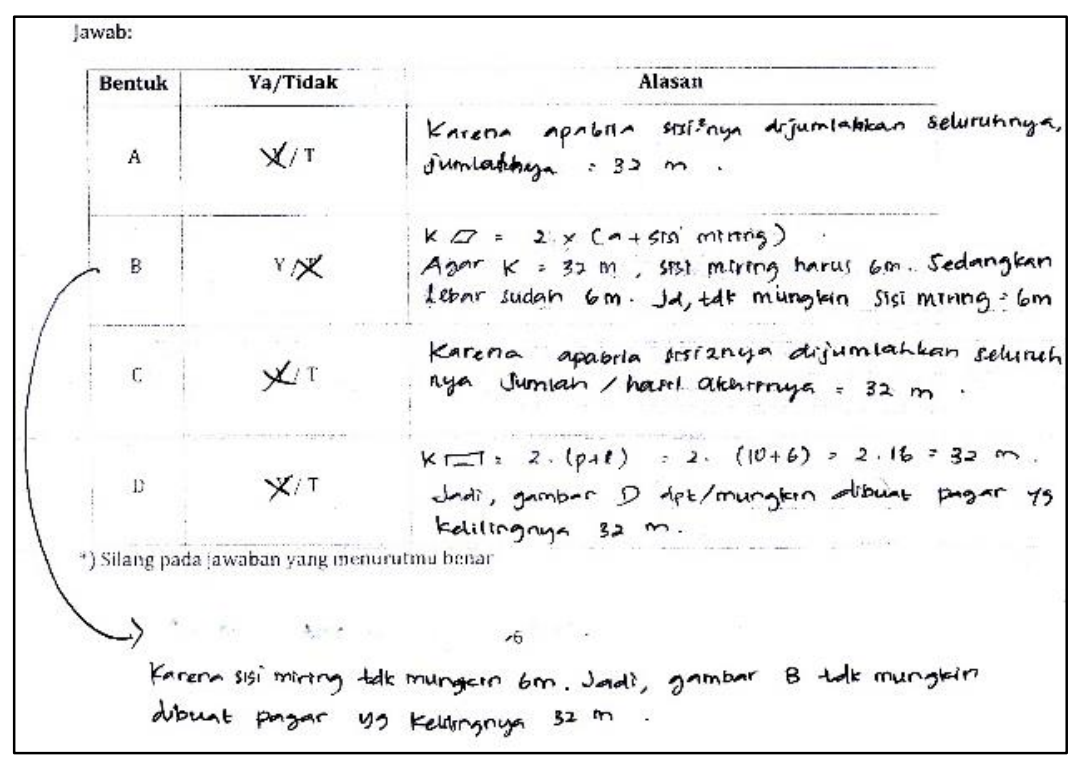

Gambar 4. Jawaban Subjek Converger Atas pada Soal nomor 6

Karakteristik lain yang dimiliki subjek Converger menurut Ghufron \& Risnawita (2014) ialah mampu mengintegrasikan apa yang diamatinya ke dalam sebuah teori. Nampak pada soal nomor 6, Subjek mengintegrasikan fakta temuannya ke dalam teori atau pengetahuan yang ada sehingga subjek dapat menyimpulkan secara tepat. 
Pada soal nomor 5, Subjek Converger Atas mampu memahami permasalahan dengan sempurna. Secara khusus, subjek mampu memilih, membandingkan dan mengevaluasi dengan tepat strategi pemecahan yang diberikan pada soal. Subjek mampu mengevaluasi jawaban yang mungkin berdasarkan opsi jawaban pada lembar soal.

Subjek Converger Tengah mampu menyelesaikan permasalahan kemampuan literasi matematika level 2, 5 dan 6 kemudian kurang mampu pada soal level 3. Pada dua soal kemampuan literasi matematika level 3, subjek hanya mampu menyelesaikan permasalahan nomor 3. Oleh karena itu, Subjek dikategorikan dalam kurang mampu dalam mengerjakan soal level 3. Subjek Converger Tengah kebingungan ketika menyelesaikan permasalahan yang membutuhkan analisis mendalam layaknya soal nomor 2 dan 4 .

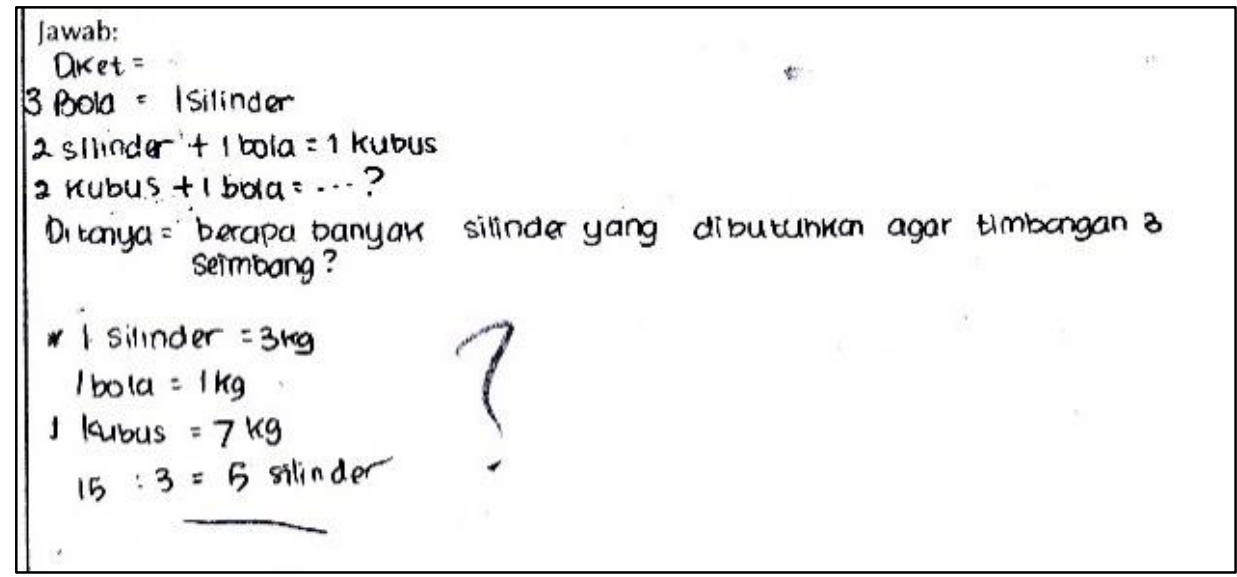

Gambar 5. Jawaban Subjek Converger Tengah pada Soal nomor 2

Pada soal tes kemampuan literasi level 6, subjek Converger Tengah menggunakan cara yang berbeda dengan subjek Converger Atas. Subjek Converger Tengah menemukan solusi praktisnya sendiri dari temuan yang ditemukannya. Subjek Converger Tengah mencari perkiraan ukuran untuk menyelesaikan permasalahan.

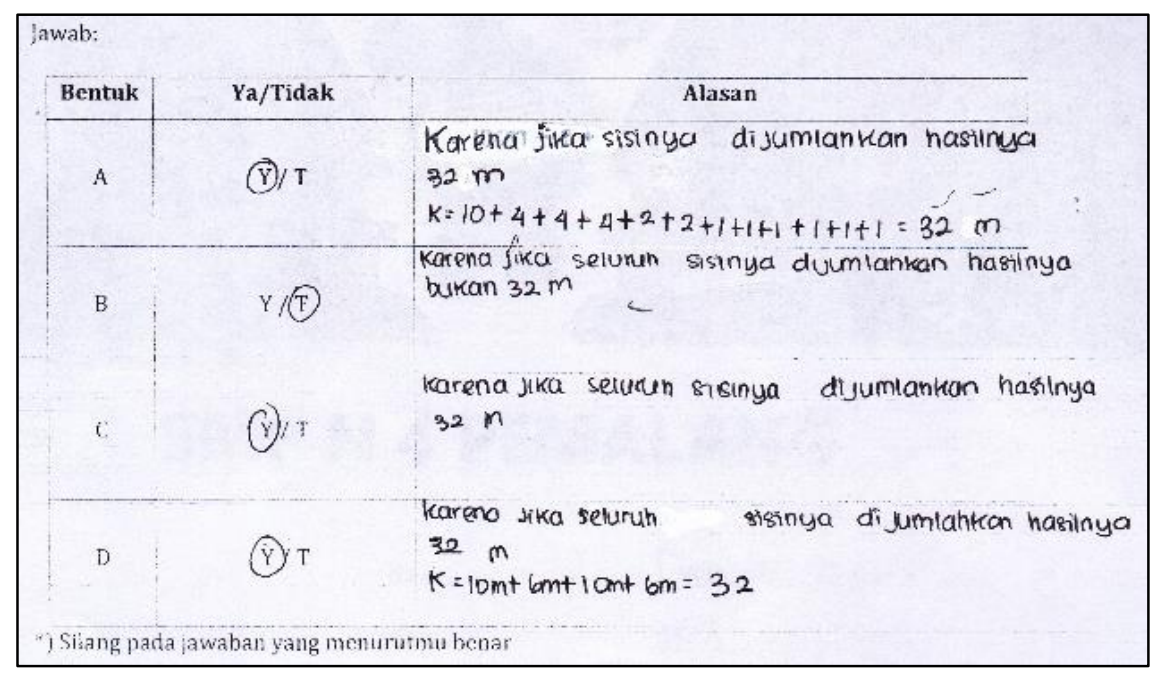

Gambar 6. Jawaban Subjek Converger Tengah pada Soal nomor 6

Subjek dengan gaya belajar Converger Bawah mampu menyelesaikan permasalahan kemampuan literasi matematika level 2 dan 3. Pada soal dengan kemampuan literasi level 4, subjek dikategorikan ke dalam kurang mampu. Subjek Converger Bawah mampu menyelesaikan permasalahan yang diberikan namun tidak mengikuti instruksi penulisan jawaban sehingga jawaban yang ditulisakannya dinilai belum maksimal. Pada soal kemampuan literasi level 5, subjek belum mampu mengidentifikasi permasalahan yang diberikan. Secara khusus subjek Converger Bawah 
sebenarnya mampu untuk menyelesaikan permasalahan literasi matematika level 6. Dalam wawancara yang dilakukan subjek mengetahui dan mampu mengomunikasikan solusi pemecahan masalah.

Kekurangan dari subjek Converger Bawah yakni belum menuliskan pekerjaannya secara sistematis dan matematis. Subjek seringkali belum menuliskan keterangan diketahui dan jawabannya secara lengkap.

Subjek gaya belajar Converger yang diteliti mempunyai karakteristik yang berbeda-beda. Kesamaan dari tiga subjek tesebut yakni mempunyai kemampuan dalam pemecahan masalah dan pengambilan keputusan, subjek Converger mampu menemukan fungsi atau solusi praktis dari berbagai ide dan teori (Kolb \& Kolb, 2005). Kemudian subjek Converger nampak dominan menggunakan logikanya dalam mengerjakan permasalahan yang diberikan. Ini dikarenakan gaya belajar Converger merupakan kombinasi dari dua pendekatan proses belajar yakni Pemikiran/ Konseptualisasi Abstrack (Abstrack Conceptualization) dan tindakan/experimen aktif (Active Experimentation) (Kolb, 1984). Dalam Ghufron dan Risnawita (2014) kuadran pemikiran memiliki ciri khas cenderung berpikir dengan pendekatan analitis, pendekatan terhadap masalah dengan logika.

Subjek Converger memiliki kelebihan yakni kemampuan komunikasi yang baik dari pada gaya belajar yang lain (Fatkhiyyah, Winarso \& Manfaat, 2019). Subjek mampu memberikan penjelasan jawabannya secara lugas dan lancar. Kemudian, secara khusus subjek Converger Atas dan Tengah mampu menuliskan jawabannya secara sistematis, lengkap dan jelas. Data ketercapaian level KLM gaya belajar Converger dapat dilihat pada Tabel 8.

Tabel 8. Ketercapaian Level KLM Gaya Belajar Converger

\begin{tabular}{lllll}
\hline Level & No & Converger Atas & Converger Tengah & Converger Bawah \\
\hline 2 & 1 & Mampu & Mampu & Mampu \\
3 & 2 & Mampu & Tidak Mampu & Mampu \\
4 & 3 & Mampu & Mampu & Mampu \\
5 & 4 & Mampu & Tidak Mampu & Kurang Mampu \\
6 & 5 & Mampu & Mampu & Tidak Mampu \\
\hline
\end{tabular}

\section{Kemampuan literasi matematika peserta didik gaya belajar Accomodator}

Subjek Gaya belajar Accomodator yang diteliti memiliki ketuntasan level kemampuan literasi matematika yang berbeda-beda. Subjek Accomodator Atas dapat menyelesaikan soal dengan kemampuan literasi level 3, 4, 5 dan 6. Pada soal level 2, subjek dikategorikan ke dalam kurang mampu karena pada tesnya subjek terpengaruh temannya sehingga dirinya menuliskan jawaban yang kurang tepat.

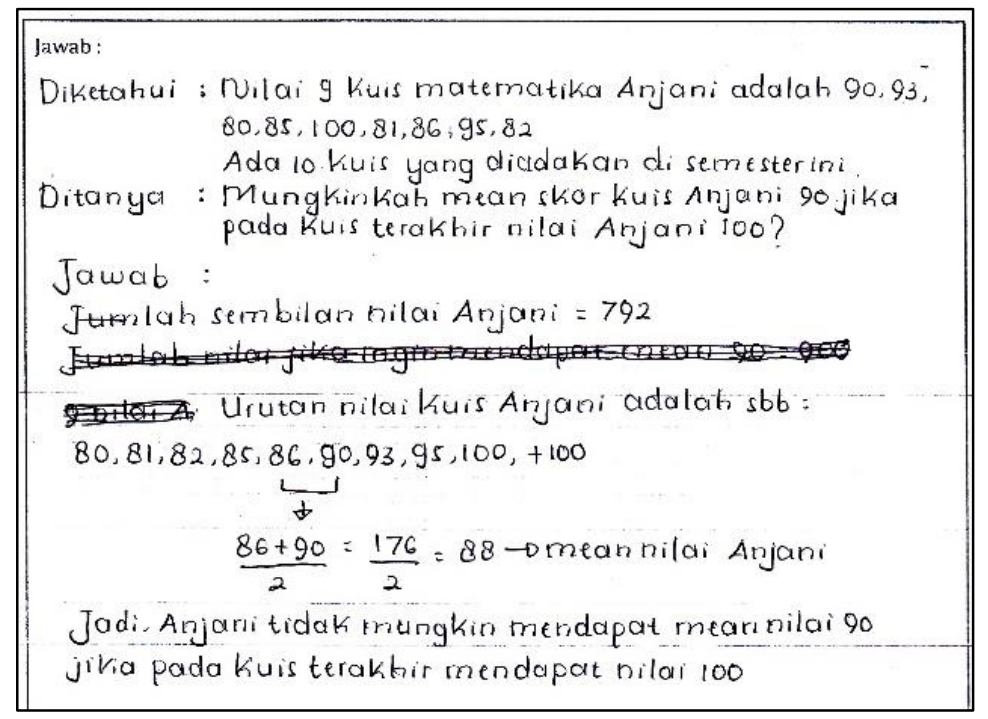

Gambar 7. Jawaban Subjek Accomodator Atas pada Soal Nomor 1 
Subjek Accomodator Atas mampu menyelesaikan permasalahan yang membutuhkan kemampuan berpikir tingkat tinggi. Dalam penelitian yang dilakukan Subjek Accomodator mengungkapkan dirinya seringkali melakukan diskusi untuk memecahkan permasalahan yang diberikan. Subjek Accomodator Atas gemar melibatkan pengalaman pribadi dalam menyelesaikan permasalahan. Subjek Accomodator Atas mengungkapkan dirinya mengintegrasikan pengalaman yang dialami untuk menyelesaikan permasalahan nomor 2. Kemudian menggunakan dirinya sendiri untuk menerka ukuran untuk soal nomor 5.

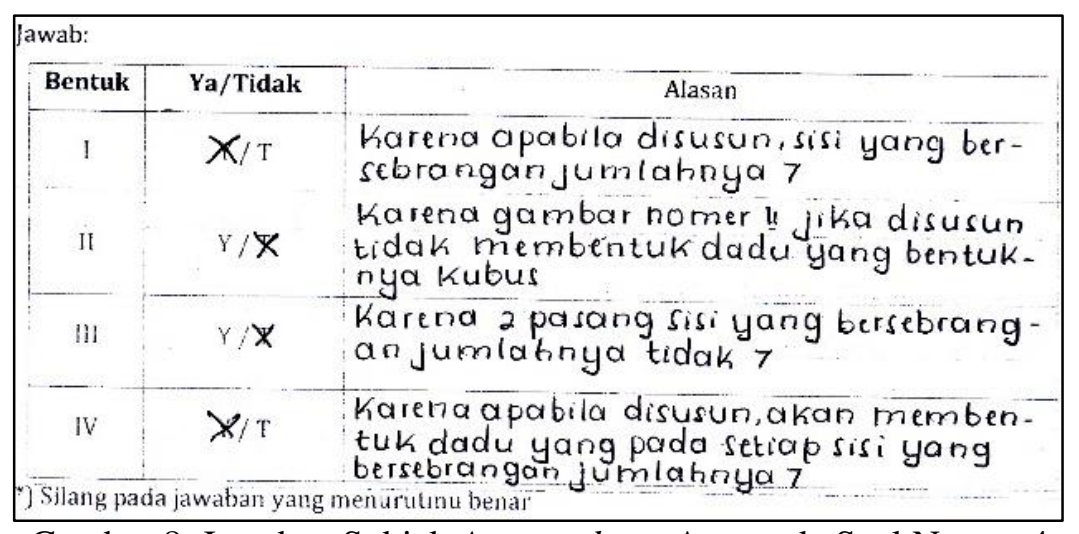

Gambar 8. Jawaban Subjek Accomodator Atas pada Soal Nomor 4

Subjek Accomodator Tengah hanya mampu menyelesaikan permasalahan dengan kemampuan literasi matematika level 2 dan 3 karena belum mampu mengidentifikasi permasalahan yang diberikan dengan baik. Subjek Accomodator Tengah masih bermasalah dalam menentukan strategi penyelesaian yang tepat untuk soal yang diberikan.

Sedangkan Accomodator Bawah hanya mampu mencapai kemampuan literasi level 2 dan kurang mampu menyelesaikan permasalahan kemampuan literasi matematika level 3. Secara umum Subjek Accomodator mempunyai karakteristik yakni mempertimbangkan pendapat orang lain untuk mendapatkan masukan, dan memilih cara bertukar pikiran atau diskusi untuk menyelesaikan permasalahan (Ghufron \& Risnawita 2014). Subjek Accomodator Bawah masih bermasalah dalam menentukan strategi penyelesaian yang tepat untuk soal yang diberikan. Data ketercapaian level KLM gaya belajar Accomodator dapat dilihat pada Tabel 9.

Tabel 9. Ketercapaian Level KLM Gaya Belajar Accomodator

\begin{tabular}{ccccc}
\hline Level & No & Accomodator Atas & Accomodator Tengah & Accomodator Bawah \\
\hline 2 & 1 & Kurang Mampu & Mampu & Mampu \\
3 & 2 & Mampu & Mampu & Mampu \\
& 3 & Mampu & Mampu & Tidak Mampu \\
4 & 4 & Mampu & Tidak Mampu & Tidak Mampu \\
5 & 5 & Mampu & Tidak Mampu & Tidak Mampu \\
6 & 6 & Mampu & Tidak Mampu & Tidak Mampu \\
\hline
\end{tabular}

\section{SIMPULAN}

Berdasarkan hasil penelitian, diperoleh kesimpulan sebagai berikut. Secara umum Subjek Diverger mampu menyelesaikan permasalahan kemampuan literasi matematika level 2, 3 dan 5. Subjek dengan gaya belajar Assimilator Atas mampu menyelesaikan permasalahan kemampuan literasi matematika level 2, 3, 4, 5 dan 6. Assimilator Tengah mampu menyelesaikan permasalahan kemampuan literasi matematika level 2, 3, 5 dan 6. Sedangkan subjek Assimilator Bawah hanya mampu memecahkan permasalahan kemampuan literasi matematika level 2, 3 dan 5. Subjek gaya belajar Converger yang diteliti mempunyai karakteristik yang berbeda-beda. Subjek Converger Atas secara sempurna mampu menyelesaikan kemampuan literasi matematika level 2, 3, 4, 5, 6. Subjek Converger Tengah mampu menyelesaikan permasalahan kemampuan literasi matematika level 2, 5 dan 6 kemudian kurang mampu pada level 3. Sedangkan Subjek dengan gaya belajar Converger Bawah mampu menyelesaikan permasalahan kemampuan literasi matematika level 2 dan 3 kemudian 
kurang mampu pada level 4. Subjek Gaya belajar Accomodator yang diteliti memiliki ketuntasan level kemampuan literasi matematika yang berbeda-beda. Subjek Accomodator Atas dapat menyelesaikan soal dengan kemampuan literasi level 3, 4, 5 dan 6 kemudian kurang mampu pada level 2. Subjek Accomodator Tengah hanya mampu menyelesaikan permasalahan level 2 dan 3. Sedangkan Accomodator Bawah hanya mampu mencapai kemampuan literasi level 2 dan kurang mampu menyelesaikan permasalahan kemampuan literasi matematika level 3.

\section{DAFTAR PUSTAKA}

Arikunto, S. (2016). Dasar-Dasar Evaluasi Pendidikan. Jakata: Bumi Aksara.

Azrai, E. P., \& Sulistianingrum, E. G. (2017). Pengaruh Gaya Belajar David Kolb (Diverger, Assimilator, Converger, Accomodator) terhadap Hasil Belajar Siswa pada Materi Pencemaran Lingkungan. Biosfer: Jurnal Pendidikan Biologi, 10(1), 9-16.

Fatkhiyyah, I. Winarso, W., \& Manfaat, B. (2019). Kemampuan Komunikasi Matematika Siswa ditinjau dari Perbedaan Gaya Belajar Menurut David Kolb. Jurnal Elemen, 5(2), 93-107.

Ghufron, M. N., \& Risnawita, R. (2014). Gaya Belajar: Kajian Teoretik. II. Yogyakarta: Pustaka Pelajar.

Hamidah, K. N. \& Rosyidi, A. H. (2016). Profil Penalaran Matematika Siswa SMP ditinjau dari Gaya Belajar Kolb. Jurnal Ilmiah Pendidikan Matematika, 3(5), 210-2019.

Johar, R. (2011). Domain Soal PISA untuk Literasi Matematika. Jurnal Peluang, 1, 30-41.

Juliantari, S. (2013). Kurikulum 2013 untuk Siapa. Artikel Populer https://antikorupsi.org/id/news/kurikulum-2013-untuk-siapa.

Kolb, A. Y. \& Kolb, D. A. (2005). Learning styles and learning spaces: Enhancing experiential learning in higher education. Academy of Management Learning and Education 4, 193 212.

Kolb, D. A. (1984). Experimental Learning: Experience as The Source of Learning and Development. Prentice Hall, Inc., 20-38.

Kolb. D. A. (2014). Experiential learning: Experience as the source of learning and development. Englewood Cliffs, NJ: Prentice-Hall.

Lange, J. D. (1991). Mathematics for Literacy: (In) Numerarcy. Quantitative Literacy: Why Numeracy Matters for Schools and Colleges. 75-89.

Ng, K. Y., Van Dyne, L., \& Ang, S. (2009). From Experience to Experiential Learning: Cultural intelligence as a Learning capability for global leader development. Academy of Management Learning \& Education, 8(4), 511-526.

OECD. (2016). Result From PISA 2015. Country Note, 1-8. https://www.oecd.org/pisa/PISA-2015Indonesia.pdf.

Sari, R. H. N. (2015). Literasi Matematika: Apa, Mengapa dan Bagaimana? Seminar Nasional Matematika dan Pendidikan Matematika, 713-20

Soleh, M. (2017). Pengaruh Strategi Contextual Teaching And Learning (CTL) terhadap Kemampuan Literasi Matematika Siswa Kelas VII Pada Materi Bangun Datar Di SMP Negeri 35 Batanghari," Artikel Ilmiah Universitas Jambi, 1-9. https://repository.unja.ac.id/id/eprint/721.

Stacey, K. (2011). The PISA View of Mathematical Literacy in Indonesia. Journal on Mathematics 
Education, 2(2), 95-126.

Sugiyono. (2018). Metode Penelitian Kuantitatif, Kualitatif Dan R\&D. Cetakan 27. Bandung: Alfabeta.

Suyono \& Hariyanto. (2011). Belajar dan Pembelajaran. Bandung: Remaja Rosdakarya

Syawahid, M., \& Putrawangsa, S. (2017). Kemampuan Literasi Matematika Siswa SMP Ditinjau Dari Gaya Belajar. Beta Jurnal Tadris Matematika, 10(2), 222-40. 